\title{
Assessment of surgical complications related to dental implant surgery using Clavien-Dindo Classification
}

\author{
Emrah Dilaver(0000-0003-4522-1424) ${ }^{\alpha}$, Kivanc Berke Ak(0000-0002-7623-0473) ${ }^{\alpha}$, Muazzez Suzen(0000-0001-5121-9158) ${ }^{\alpha}$,
}

Sina Uckan(0000-0003-1077-7342) ${ }^{\alpha}$

Selcuk Dent J, 2021; 8: 679-684 (Doi: 10.15311/selcukdentj.765632)

Başvuru Tarihi: 07 Temmuz 2020 Yayına Kabul Tarihi: 11 Eylül 2020

\begin{abstract}
Assessment of surgical complications related to dental implant surgery using Clavien-Dindo Classification

Background: The aim of this study is to evaluate the surgical complications encountered in the implants performed by the same surgeon between 2016-2019 using the Clavien-Dindo classification used to grade the severity of surgical complications.
\end{abstract}

Methods: This retrospective study includes a total of 1171 implants performed in 368 cases undergoing dental implant surgery. Complications related to the operation were recorded and these complications were evaluated according to the Clavien-Dindo Classification system. Possible effects of other factors such as age, gender, smoking, Diabetes mellitus and immediate implant placement on complications were also evaluated.

Results: A total of 98 complications have been reported, including flap dehiscence, numbness, infection, the apical part of the dental implant in the maxillary sinus, lack of primary stability, and cortical bone perforation. Smoking and immediate implantation were found to be risk factors for flap dehiscence ( $p$ $<0.05$ ). $54.8 \%$ of the complications were in Clavien-Dindo Class I and $28.5 \%$ in Class Illa. According to the Clavien-Dindo classification, gender, age, smoking and Diabetes Mellitus did not increase the severity of the complications encountered.

Conclusion: The Clavien-Dindo classification could serve as a useful in dental implant surgery both for standardization of complications and to help clinicians understand the consequences of complications. Wide range of using the Clavien-Dindo classification system would allow comparisons of different techniques' outcome in implant surgery among different surgeons and centers.

\section{KEYWORDS}

Clavien-Dindo classification, Surgery complications, Dental implant surgery

Dental implant surgery, similar to any other surgical procedures, has complications. In the literature; it was reported that rarely seen severe complications in the mandible could endanger life during implant surgery due to bleeding and emphysema. ${ }^{1}$ Most encountered complications during implant surgery are cortical plate perforation, bleeding, nerve injury, sinus perforation, devitalization of adjacent teeth, and lack of the primary stabilization. ${ }^{2}$ Gender, age, Diabetes Mellitus (DM),

\section{öz}

Dental İmplant Cerrahisi ile İIgili Cerrahi Komplikasyonların Clavien-Dindo Sınıflandırması kullanılarak Değerlendirilmesi

Amaç: Bu çalışmanın amacı cerrahi komplikasyonların ciddiyetini derecelendirmede kullanılan Clavien-Dindo sınıflamasını kullanarak, 2016-2019 yılları arasında aynı cerrah tarafından yapılan implantlarda karşılaşılan cerrahi komplikasyonları değerlendirmektir.

Gereç ve Yöntemler: Bu retrospektif araştırma, dental implant ameliyatı geçiren 368 vakada yapılan toplam 1171 implantı içermektedir. Ameliyatla ilgili karşılașılan komplikasyonlar kaydedildi ve bu komplikasyonlar Clavien-Dindo Sınıflandırma sistemine göre değerlendirildi. Yaș, cinsiyet, sigara içme, Diabetes mellitus ve immediat implant yerleştirilmesi gibi diğer faktörlerin de komplikasyonlar üzerinde olası etkileri ayrıca değerlendirildi.

Bulgular: Flep dehisensi, hissizlik, enfeksiyon, dental implantın apikal kısmının maksiller sinüs içinde olması, primer stabilite eksikliği ve kortikal kemik perforasyonu dahil toplam 98 komplikasyonla karşılaşılmıştır. Sigara içmenin ve immediate implantasyonun, flep dehisensi meydana gelmesi açısından risk faktörü olduğu bulundu $(p<0.05)$. Karşılaşılan komplikasyonların \%54.8'i Clavien-Dindo Sınıf I ve \% 28.5'i sınıf Illa içerisindeydi. Clavien-Dindo sınıflamasına göre cinsiyet, yaş, sigara içme ve Diabetes Mellitus'un karşılaşılan komplikasyonların ciddiyetini artırmadığı görüldü $(p>0.05)$

Sonuç: Clavien-Dindo sınıflandırması dental implant cerrahisinde hem komplikasyonların standardizasyonu hem de klinisyenlerin komplikasyonların sonuçlarını anlamalarına yardımcı olmak için yararlı olabilir. Clavien-Dindo sınıflandırma sisteminin geniş bir yelpazede kullanıması, implant cerrahisinde farklı tekniklerde karşılașılan komplikasyonların farklı cerrahlar ve merkezler arasında karşılaştııımasına olanak sağlayacaktır.

\section{ANAHTAR KELIMELER}

Clavien-Dindo sınıflandırması, Cerrahi komplikasyonlar, Dental implant cerrahisi

smoking, head \& neck radiation, and postmenopausal estrogen therapy are the risk factors for complications. ${ }^{3,4}$ Avoiding surgical complications begins with careful assessment of patients, including systemic status, evaluating the anatomy of jaws and surgical technique to be used. However, when we encountered complications during or at the postoperative healing period, overcoming these problems is also essential.

\footnotetext{
${ }^{\alpha}$ İstanbul Medipol University Faculty of Dentistry, Department of Oral and Maxillofacial Surgery, İstanbul, Turkey.
} 
Another way to assess complications related to surgical procedures is based on the form of treatment of the complication. The Clavien-Dindo Classification can be used in all surgery fields, classify complications from Grade I to $V$ with increasing severity eliminating confusing terms which are minor and major complication. ${ }^{5,6}$ With this classification, clinicians could compare results in different periods within various institutions. Researchers also could examine the treatment methods and complications in a standardized way. ${ }^{6}$ For this reason, using this classification in dental implant surgery may be beneficial for clinicians. In our knowledge, there is no study about the categorization of dental implants surgery complications using this classification.

The purpose of this study was to examine the most common types of complications related to dental implant surgery using The Clavien-Dindo Classification. We also investigated the effect of systemic status and immediate placement on different complications.

\section{MATERIALS AND METHODS}

This study was approved by Medipol University Ethical Committee No: 10840098-604.01.01-E.12197 in compliance with the Declaration of Helsinki.

This retrospective study involved patients who underwent dental implant therapy from September 2016 to February 2020 at the Oral and Maxillofacial Department of Medipol University School of Dentistry by same surgeon (E.D). Patients with missing clinician reports and patients requiring additional surgery for dental implant placement such as sinus lift, ridge split, intraoral, or extraoral block graft were excluded from the study due to that complications of each additional surgeries were specific and different which affect standardization of study outcomes.

Routine follow-up program after implant surgery in our clinic, patients are called for follow-up on the 3rd, 10th day, and 1 month after surgery. If any problems were encountered during the controls, the intervals were tightened.

\section{Variables:}

The dependent variable was the presence of complications at per implants. The following complications during the perioperative and postoperative period were considered:

- Sensory disturbance: If the patient describes numbness in about approximately 2 weeks later, it was named as a sensory disturbance.

- Infection: Edema, pus flow, and pain around the dental implant area during the osseointegration period were defined as an infection.
- Flap dehiscence: If the wound edges are free approximately even ten days after implant surgery, this was defined as opening the wound.

- The extension of a dental implant into the maxillary sinus: It was defined as penetrance of dental implant's apical portion of the maxillary sinus. This complication was detected during surgery and validated through panoramic radiography.

- Lack of primary stability: It is defined as the insertion of a dental implant with lower torque than $30 \mathrm{Ncm}$.

- Cortical plate perforation: If there were perforations on the buccal or lingual cortical layer during drilling, this defined as cortical plate perforation.

Independent variables such as age, whether it is immediate or not, smoking, Diabetes mellitus were also noted whether it affects complications.

Investigated surgical complications were rated from Grade I to Grade V using The Clavien-Dindo Classification (Table 1).

Table 1.

\section{Clavien-Dindo classification schema of surgical complications}

\begin{tabular}{|ll|}
\hline Definition \\
\hline Grade I & $\begin{array}{l}\text { any deviation from the ordinary post-operative course without giving } \\
\text { pharmacological and surgical interventions. }\end{array}$ \\
\hline Grade II & complication requires pharmacological treatment \\
\hline Grade IIIa & complication requires surgical intervention under local anesthesia \\
\hline Grade IIIb & complications requires surgical intervention under general anesthesia \\
\hline Grade IV & $\begin{array}{l}\text { complications are related to life-threatening complications that require } \\
\text { intensive care unit management }\end{array}$ \\
\hline Grade V & complications are related to patient's death. \\
\hline
\end{tabular}

\section{Statistical Analysis}

Statistical analysis was performed using the Statistical Package for the Social Sciences (SPSS for Windows, version 18.0, SPSS Inc., Chicago, USA). Categorical variables were analyzed with the chi-squared test, Fisher's exact test. Multivariate regression analysis was performed for assessing effect of dependant variables on complications. $\mathrm{P}$ values $<0.05$ were considered as statistically significant.

\section{RESULTS}

A total of 1171 dental implants were performed on 369 patients. The mean age of patients was $48.01 \pm 10.37$, with 578 dental implants in maxilla, 593 dental implants in the mandible. Women represented $45.7 \%(n=535)$ and men represented $54,3 \%(n=636)$ which gave a ratio 1:1.19. Dental implants were placed immediately in $13.9 \%(n=163)$ of the patients following tooth 
extraction. When we examine the systemic status of patients, $19.3 \%(n=226)$ implants were in patients who smoke, and $4,9 \% \quad(n=57)$ implants were in patients with DM.

The complication rate was $3.3 \%$ (20 mandible, 18 maxilla) for flap dehiscence, $2.3 \%$ ( fourteen in the mandible) for sensory disturbance, $1.45 \%$ (nine mandible, seven maxilla) for infection, $2.7 \%(n=16)$ for extension of the dental implant's apical portion into the maxillary sinus, $0.6 \%$ (two mandible, five maxilla) for weak primary stabilization and $0.6 \%$ (four mandible, three maxilla) for cortical plate perforation (Table 2).

Table 2.

\section{Type and frequency of complications}

\begin{tabular}{|c|c|c|c|}
\hline Complications & & $\mathbf{n}$ & $\%$ \\
\hline \multirow{2}{*}{ Flap Dehiscence } & Maxilla & 20 & \multirow{2}{*}{3.3} \\
\hline & Mandible & 18 & \\
\hline Sensory Disturbance* & Mandible & 14 & 2.3 \\
\hline \multirow{2}{*}{ Infection } & Maxilla & 7 & \multirow{2}{*}{1.45} \\
\hline & Mandible & 9 & \\
\hline $\begin{array}{l}\text { The extension of a dental } \\
\text { implant's apical portion into } \\
\text { maxillary sinus }\end{array}$ & Maxilla & 16 & 2.7 \\
\hline \multirow{2}{*}{ Lack of primary stability* } & Maxilla & 2 & \multirow{2}{*}{0.6} \\
\hline & Mandible & 5 & \\
\hline \multirow{2}{*}{ Cortical plate perforation } & Maxilla & 3 & \multirow{2}{*}{0.6} \\
\hline & Mandible & 4 & \\
\hline
\end{tabular}

* Complication rate was calculated for all dental implants in one jaw

Serious bleeding, jaw fracture and devitalization of adjacent teeth was not seen in our patients.

There was found significance relation between flap dehiscence and immediate implant placement $(p=0.000)$ (Table 3).

\section{Table 3.}

\section{Effect of variables on complications}

\begin{tabular}{|lllll|} 
& Age & Smoking & $\begin{array}{l}\text { Diabetes } \\
\text { mellitus }\end{array}$ & $\begin{array}{l}\text { Immediate } \\
\text { placement }\end{array}$ \\
\hline Flap Dehiscence & $p=0.938$ & $p=0.025^{*}$ & $p=0.688$ & $p=0.000^{*}$ \\
\hline Infection & $p=0.007^{*}$ & $p=0.094$ & $p=0.570$ & $p=0.002^{*}$
\end{tabular}

Multivariate regression analysis analysis test performed

* statistically significant

There was also a significant relation difference between flap dehiscence and smoking $(p=0,025)$. However, we did not find a relation between flap dehiscence and DM $(p=0,688)$. Immediate implant placement and age was found as risk factors regarding the presence of infection $(p<0.05)$.

A statistically significant relationship was found between early failure and extension of the dental implant's apical portion into maxillary sinus (Fisher's exact test,$p=0.000$ ).

The distribution of surgical complications per dental implant according to Clavien-Dindo classification was $53(54.08 \%)$ for grade I, $17(17.3 \%)$ for grade II, $28(28.5 \%)$ for grade III-a (Table 4$)$.

Table 4.

Categorization of number of complications according to Clavien-Dindo Classification

\begin{tabular}{|lllll|}
\hline Complications & Grade I & Grade II & $\begin{array}{l}\text { Grade } \\
\text { IIla }\end{array}$ & Total \\
\hline Flap Dehiscence & 19 & 10 & 9 & 38 \\
\hline Sensory Disturbance* & 9 & 3 & 2 & 14 \\
\hline $\begin{array}{l}\text { Infection } \\
\text { The extension of a dental implant's } \\
\text { apical portion in maxillary sinus }\end{array}$ & 13 & 0 & 3 & 16 \\
\hline Lack of primary stability* & 6 & 1 & 0 & 7 \\
\hline Cortical plate perforation & 6 & 0 & 1 & 7 \\
\hline Total & 53 & 17 & 28 & 98 \\
\hline
\end{tabular}

Gender, age, smoking, and DM were not significant in complications' grade. (Fisher's exact test $, p>0.05)$. While 19 of the flap dehiscence in 38 dental implants were healed spontaneously (Grade I), 10 of them healed with pharmacological therapy and irrigation with sterile saline solution (Grade II), the remaining nine required surgical intervention (Grade IIla). Surgical intervention was required in 13 of 16 implants having an infection (Grade Illa). 6 of 7 implants having weak primary stability categorized in Grade I. 13 of 16 dental implants whose apical portion penetrated maxillary sinus was categorized in grade I, three dental implants categorized in grade IIla. While 2 of 14 dental implants related to sensory disturbances categorized in grade IIIa, 11 of them categorized in grade I, and one was categorized in grade II.

\section{DISCUSSION}

Dental implants are a predictable, safe, and widely used for oral rehabilitation with approximately $90 \%$ with success rate. ${ }^{7}$ Although, surgical complication percent is low, management of these complications is essential. The most frequently reported complications in dental implant surgery were flap dehiscence, nerve damage, devitalization of the adjacent tooth, hematoma, bone fracture, displacement of implants in the maxillary sinus, sinus membrane perforation, neuropathic pain, infection, cortical plate perforation, and lack of primary stability. In this study, we categorized the management of complications using the ClavienDindo classification along with risk factors.

Flap dehiscence was the most seen frequent complication in our study, which is considered as 
the split of the surgical incision margin resulting in the exposure of the implant and/or surrounding tissues. ${ }^{9}$ (Figure 1)

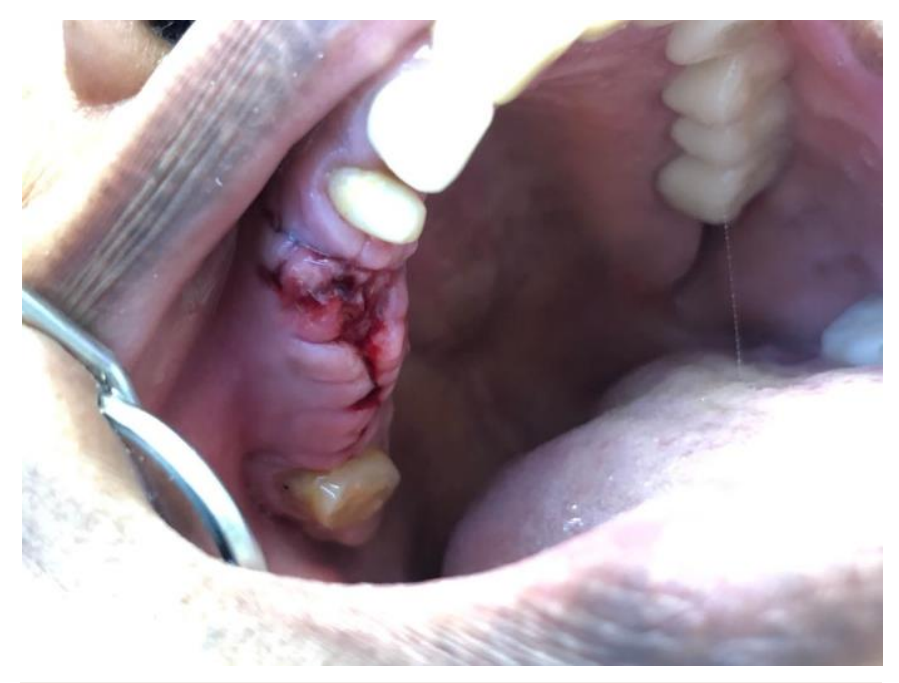

Figure 1

Flap dehiscence around dental implant

The prevalence in previous studies ${ }^{9}$, which was $4.6 \%$ to $40 \%$, came accorandance with our results (3.3\%). Several reasons which disrupt the blood supply to mucoperiosteal tissue and prolong soft tissue healing are traumatic surgical technique, guided tissue regenerative materials, bone grafting, radiation therapy, fragile mucosa, failure to ensure passive closure, presence of massive edema or hematoma, and insufficient or excessive tension of the suture are responsible for this complication. ${ }^{10,11}$ In our study, flap dehiscence incidence in immediately placed implant were higher. There were two possible explanation of higher incidence, one was the vascularization of the flap due to relaxing incisions on the periosteum and other was appliying biomaterials around implant. The majority of the 38 implants where flap dehiscence occurred was seen in Grade I and Grade II means that ten implants in Grade II were resolved by antibiotic therapy ( $1 \mathrm{gr}$ amoxicillin clavulanate for one week) and irrigation with sterile saline solution and 19 implants in Grade I were only followed. It was required surgical intervention (resuturing) in nine implants in Grade Illa (Table 4).

Another complication we focused on was the protruding of the implant's apical portion into the maxillary sinus. Theoretically, maxillary sinus drainage may be altered if the implant's apical portion is placed into the maxillary sinus. ${ }^{12}$ Jae-Hyung Jung et al. ${ }^{12}$ also reported that extension of the implant into sinus was not related to maxillary sinus infection. However, Jong Seung Kim et al. ${ }^{13}$ reported in the meta-analysis that Schneiderian membrane rupture was one of the two causes of post-operative sinusitis. The current study found that 3 of 16 dental implants having penetrance into the maxillary sinus categorized in Grade Illa was failed after 3 months(Table 4). To solve this complication, we have placed shorter and wider implant than before.

The occurrence of sensory disturbances in the literature was between $0.13 \%$ to $37 \% .{ }^{14}$ Nerve injuries during implant's bed osteotomy and/or at the placement of the dental implant can be caused by various reasons such as insufficient preoperative planning of anatomy and extreme stretching of flap. ${ }^{14,15}$ In our research, numbness caused by compression of the inferior alveolar nerve was seen in two implants categorized in Grade Illa. In these cases, implants replaced by shorter ones. At one month follow-up, the numbness complaint ended. (Figure 2).

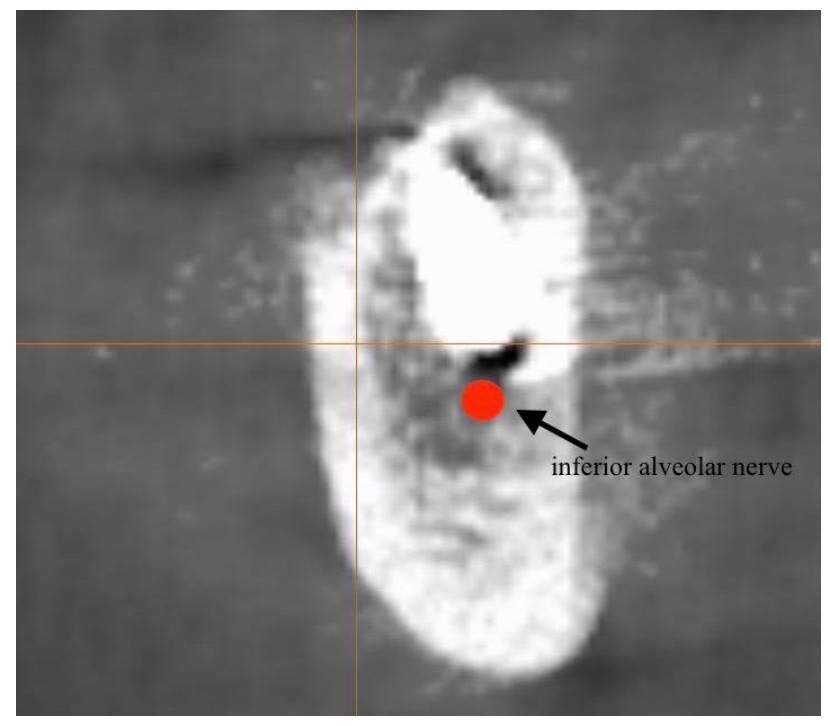

Figure 2

Relation of dental implant's apical portion with inferior alveolar canal

Nine implants in Grade I were only followed and pharmacological treatment (oral administration of vitamin B12 and corticosteroid) was applied in 3 implants in Grade 2 (Table 4).

One of the reasons for early implant failure is infection. ${ }^{16}$ Pathogenic bacteria can produce destructive inflammatory mediators, causing direct or indirect impairment of implant osseointegration. Direct sources of bacterial contamination during surgery, which are surgical instruments, gloves, air circulation in the operating room, air expired by the patient, salivation in the oral cavity, and peri-oral tissue cause in abscesses around the implant. Sutures and poorly placed cap screws may also reason for the infection. ${ }^{17,18}$ It can still be argued that the use of a prophylactic and postoperative antibiotic to prevent post-operative infection in dental implant surgery. ${ }^{16,19}$ A previous study stated that using pre-operative $0.12 \%$ Chlorhexidine Gluconate has been proven to reduce the complications associated with infection. ${ }^{20}$ Patients in our study were gargled with 60 -sec chlorhexidine 
gluconate before surgery, and antibiotics were administered for one week postoperatively. We have encountered 16 dental implant infection in our study. Twelve of them in Grade Illa resulted in the renewal of implant; one in Grade in Illa required surgical drainage, and three dental implants in Grade II were healed with using pharmacological therapy (readministration of 1 gr amoxicillin clavulanic acid for one week) (Table 4).

The selection of the systemically appropriate patient is one of the most important factors affecting success in implant therapy. Pathologic conditions such as diabetes mellitus which were responsible for disruption of microcirculation can cause a delay in wound healing. ${ }^{21-23}$ It has been reported that DM did not have any impact on increasing the implant survival and success rate if the patients are under medical control. It was reported in the literature that the risk of peri implantitis does not increase even if glycemic control is not provided. ${ }^{24,25}$ In our study, we performed dental implant therapy in patients with controlled DM. Maybe that's why we could not find a relationship between DM and failure of early osseointegration and flap dehiscence $(p>0.05)$. Another factor assessed as a risk factor is smoking. In the previous study reported that there was a correlation between smoking and impaired wound healing, including dehiscence and infection rates. ${ }^{26}$ Similar to these results, a statistical relationship was found in patients who smoke regarding the occurrence of infection and flap dehiscence $(p<0.05)$. In our study, smoking and DM did not increase the severity of the complications according to the ClavienDindo classification.

Clavien Dindo classification has been used in medicine in many surgical procedures to evaluate the severity of complications. ${ }^{5,6}$ In previous study ${ }^{5}$ stated that minor and major complications have been well categorized without using these terms via The Clavien-Dindo classification. Surgery complications in implant dentistry was generally categorized depending on the time they emerge: early and late. ${ }^{2}$ Considering specific complications encountered in early and late period, classification of severity was subjective rather than based on objective criteria. As a result of trouble in comprehensive evaluation, sharing decision with patients or other clinicians for improving prognosis is not satisfactory. Clavien Dindo classification may be helpful for overcoming these problems in implant dentistry.

\section{CONCLUSION}

Clavien-Dindo classification could be useful for clinicians performing dental implant surgery routinely to categorize surgical complications by severity. Regarding Clavien-Dindo classification, most of the complications were classified in grade I showing that complications in dental implant surgery tend to a low complexity of treatment. Surgery complications in our study classified as Grade I, Grade II and Grade IIla. We didn't observe a higher grade than Grade IIla. However; there were reported severe complications in the literature that can take higher grades according to Clavien-Dindo classification. Because of that, further studies in larger samples are needed. 


\section{REFERENCES}

1. Givol N, Chaushu G, Halamish-Shani T, Taicher S. Emergency Tracheostomy Following LifeThreatening Hemorrhage in the Floor of the Mouth During Immediate Implant Placement in the Mandibular Canine Region. J Periodontol 2000;71:1893-5.

2. Pelayo JL, Diago MP, Bowen EM, Diago MP. Intraoperative complications during oral implantology. Med Oral Patol Oral Cir Bucal 2008;13:239-43.

3. Chrcanovic BR, Albrektsson T, Wennerberg A. Smoking and dental implants: A systematic review and meta-analysis. J Dent 2015;43:487-98.

4. Alberto Monje, Andres Catena WSB. Association between Diabetes Mellitus/Hyperglycemia and PeriImplant Diseases: Systematic Review and MetaAnalysis. Int J Lab Hematol 2016;38:42-9.

5. Clavien PA, Barkun J, De Oliveira ML, Vauthey JN, Dindo D, Schulick RD, et al. The clavien-dindo classification of surgical complications: Five-year experience. Ann Surg 2009; 250:187-196

6. Bolliger M, Kroehnert JA, Molineus F, Kandioler D, Schindl M, Riss P. Experiences with the standardized classification of surgical complications (ClavienDindo) in general surgery patients. Eur Surg - Acta Chir Austriaca 2018;50:256-61.

7. Castellanos-Cosano L, Rodriguez-Perez A, Spinato $\mathrm{S}$, Wainwright M, Machuca-Portillo G, Serrera-Figallo $M A$, et al. Descriptive retrospective study analyzing relevant factors related to dental implant failure. Med Oral Patol Oral y Cir Bucal 2019;24:e726-38.

8. Annibali S, Ripari M, LA Monaca G, Tonoli F, Cristalli MP. Local complications in dental implant surgery: prevention and treatment. Oral Implantol (Rome) 2008;1:21-33.

9. Suzuki JB., Resnik RR. Wound Dehiscence: Incision Line Opening. Resnik RR, and Misch CEBT-MAC in Ol, editors. Mosby; Misch's avoiding complications in oral implantology 2018. p. 402-39.

10. Al-Juboori MJ, Filho LC . The influence of flap design and technique on dental implant success, prognosis and morbidity: Mini review. Int J Contemp Dent Med Rev 2015;2015:4-7.

11. Sadig W, Almas K. Risk factors and management of dehiscent wounds in implant dentistry. Implant Dent 2004;13:140-7.

12. Jung JH, Choi BH, Zhu SJ, Lee SH, Huh JY, You TM, et al. The effects of exposing dental implants to the maxillary sinus cavity on sinus complications. Oral Surgery, Oral Med Oral Pathol Oral Radiol Endodontology 2006;102:602-5.

13. Kim JS, Choi SM, Yoon JH, Lee EJ, Yoon J, Kwon $\mathrm{SH}$, et al. What Affects Postoperative Sinusitis and Implant Failure after Dental Implant: A Meta-analysis. Otolaryngol - Head Neck Surg (United States) 2019;160:974-84.

14. Lin CS, Wu SY, Huang HY, Lai YL. Systematic review and meta-analysis on incidence of altered sensation of mandibular implant surgery. PLoS One 2016;11:1-19.
15. Steinberg MJ, Kelly PD. Implant-related Nerve Injuries. Dent Clin North Am 2015;59:357-73.

16. Braun RS, Chambrone L, Khouly I. Prophylactic antibiotic regimens in dental implant failure: $A$ systematic review and meta-analysis. J Am Dent Assoc 2019;150:e61-91.

17. Lafaurie GI, Sabogal MA, Castillo DM, Rincón MV, Gómez LA, Lesmes YA, et al. Microbiome and Microbial Biofilm Profiles of Peri-Implantitis: A Systematic Review. J Periodontol 2017;88:1066-89.

18. Veitz-Keenan A, Ferraiolo DM, Keenan JR. Impact of asepsis technique on implant success. A review. Eur $\mathrm{J}$ Oral Implantol 2018;11 Suppl 1:S113-21.

19. Gill AS, Morrissey H, Rahman A. A systematic review and meta-analysis evaluating antibiotic prophylaxis in dental implants and extraction procedures. Med 2018;54:1-27.

20. Lambert PM, Morris HF, Ochi S. The influence of $0.12 \%$ chlorhexidine digluconate rinses on the incidence of infectious complications and implant success. J Oral Maxillofac Surg 1997;55:25-30.

21. Martin A, Komada MR, Sane DC. Abnormal angiogenesis in diabetes mellitus. Med Res Rev 2003;23:117-45.

22. Ekmektzoglou KA, Zografos GC. A concomitant review of the effects of diabetes mellitus and hypothyroidism in wound healing. World $\mathrm{J}$ Gastroenterol 2006;12:2721-9.

23. Broughton G, Janis JE, Attinger CE. Wound healing: An overview. Plast Reconstr Surg 2006;117:1-32.

24. Anner R, Grossmann Y, Anner Y, Levin L. Smoking, diabetes mellitus, periodontitis, and supportive periodontal treatment as factors associated with dental implant survival: A long-term retrospective evaluation of patients followed for up to 10 years. Implant Dent 2010;19:57-64.

25. Wu X, Al-Abedalla K, Eimar $\mathrm{H}$, Arekunnath Madathil $\mathrm{S}$, Abi-Nader S, Daniel NG, et al. Antihypertensive Medications and the Survival Rate of Osseointegrated Dental Implants: A Cohort Study. Clin Implant Dent Relat Res 2016;18:1171-82.

26. Jones JK, Triplett RG. The relationship of cigarette smoking to impaired intraoral wound healing: a review of evidence and implications for patient care. J Oral Maxillofac Surg 1992;50:237-9; discussion 239-40.

\section{Corresponding Author:}

\section{Emrah DILAVER}

Istanbul Medipol University

Faculty of Dentistry

Department of Oral and Maxillofacial Surgery

Istanbul, Turkey

Phone : +902124534942

E-mail : emrahdilaver@gmail.com 